\title{
Treatment of Chronic Plaque Psoriasis with Etanercept and Methotrexate
}

\author{
Husam A. Salman', Fatema A. Al-Jaralla ${ }^{2}$, Rana K. Obeed ${ }^{3}$
}

${ }^{1}$ Department of Dermatology, College of Medicine, University of Baghdad. Iraqi and Arab Board for Dermatology \&Venereology, Baghdad Teaching Hospital, Medical City, Baghdad, Iraq. ${ }^{2}$ Department of Dermatology, College of Medicine, University of Baghdad, Baghdad, Iraq. ${ }^{3}$ Dermatology Center, Baghdad Teaching Hospital, Medical City, Baghdad, Iraq.

\section{ABSTRACT}

Abstract: psoriasis is a chronic multifactorial disease that has negative impact on the patient's quality of life. Selecting appropriate treatment for each patient must be both effective and relatively safe. Methotrexate and Etanercept are systemic therapies used for moderate - severe chronic plaque psoriasis. Objective: The aim of study is to assess the efficacy of methotrexate and etanercept in the treatment of chronic plaque psoriasis. Patients and Methods: This therapeutic, interventional comparative single centre study was carried out at the Centre of Dermatology and Venereology, Baghdad Teaching Hospital, from January 2015 -July 2017. A total of 62 patients were enrolled; divided in to two groups. Group I: Thirty-three patients (23 males and 10 females), their ages ranged between 15 and 65 years mean \pm SD $33.13 \pm 13.07$, received etanercept $50 \mathrm{mg}$ twice weekly for 3 months then once weekly thereafter. Group II: Twenty-nine patients (19 males and 10 females), their ages ranged between15 and 62 years mean $\pm S D 38.16 \pm 15.2$, received methotrexate 15 $\mathrm{mg}$ per week for six months then tapered. Both groups were followed up monthly for 6 months and their PASI score, DLQI, side effect and pictures were recorded. Results: Seven patients defaulted from the study for unknown reason,30 patients completed in etanercept group, while 25 patients completed in methotrexate group. After 12 weeks the PASI score decrease from base line $19.13 \pm 10.67$ to $6.38 \pm 4.96$ and then to $3.34 \pm 5.38$ after 24 weeks treatment with Etanercept compared to reduction in PASI score from base line $18.97 \pm 10.54$ to $5.72 \pm 4.8$ to $2.95 \pm-6.01$ after 12 weeks and 24 weeks respectively. There is significant statistical effect in the two groups. Conclusions: We conclude that both are effective monotherapy for patients with moderate to severe plaque psoriasis with tolerable side effect

Keywords: etanercept; methotrexate; psoriasis.
*Correspondence to Author: Husam A. Salman

Department of Dermatology, College of Medicine, University of Baghdad. Iraqi and Arab Board for Dermatology \& Venereology, Baghdad Teaching Hospital, Medical City, Baghdad, Iraq.

How to cite this article:

Husam A. Salman, Fatema A. Al-Jaralla, Rana K. Obeed. Treatment of Chronic Plaque Psoriasis with Etanercept and Methotrexate. American Journal of Dermatological Research and Reviews, 2020, 3:21

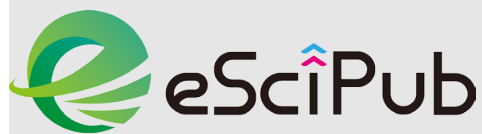
eSciPub LLC, Houston, TX USA. Website: https://escipub.com/ 


\section{Introduction}

Psoriasis is a chronic multisystemic disorder with polygenic predisposition combined with environmental factors participating in its development. [1]. It is a worldwide disease, with a prevalence in different populations varies from $0.1 \%$ to $11.8 \%$. [2] In Iraq, a study showed psoriasis frequency in the outpatient clinic was $2.3 \%$. [3] Psoriatic arthritis found to affect 5-30\% of patients with cutaneous psoriasis [4]. Studies confirmed that psoriasis is $\mathrm{s}$ a $\mathrm{T}$ cell mediated autoimmune disease in which a persistent $T$ cell stimulation by a remaining elusive antigens as to date no true auto antigen had been definitively identified [4].

Methotrexate (MTX) is an antimetabolite analog of folic acid. Dihydrofolatereductase (DHFR) converts dihydrofolate to tetrahydrofolate, which is a necessary cofactor in the synthesis of thymidylate and purine nucleotides, which, in turn, are required for DNA/RNA synthesis, inhibiting cell division in the $S$ phase.MTX competitively and irreversibly inhibits DHFR. It decreases inflammation through other mechanisms as well. By inhibiting aminoimidocarboxyamido-

ribonucleotidetransformylase, it increases local tissue concentrations of the potent antiinflammatory mediator adenosine. By inhibiting methionine synthase, MTX reduces production of the proinflammatory mediator S-adenyl methionine [5] MTX is administered weekly, the dose for psoriasis is 10-15 mg (maximum 25 $\mathrm{mg}$ ). Therapy should begin with a test dose of 2.5-7.5 mg followed 5-6 days later with a complete blood count with differential (CBC), platelet count and hepatic profile [5]. In chronic plaque psoriasis, initial improvement is observed between 1 and 7 weeks and maximum improvement can be expected after 8-12 weeks of treatment [6]. Side effects of MTX involve pancytopenia, hepatotoxicity, gastrointestinal intolerance, mucositis, alopecia, erythema multiforme, Stevens_Johnson syndrome, toxic epidermal necrolysis, skin ulceration/necrosis which may be the early sign of toxicity [7],
Accelerated rheumatoid nodulosis, Reversible lymphoproliferative disorders, when used in very high doses, MTX may cause reversible oligospermia [5]

TNF_ $\boldsymbol{\alpha}$ inhibitors: these include Etanercept, infliximab and adalimumab, these agents reduce level of TNF _a secreted by macrophages, monocyte, T-lymphocytes, keratinocyte and dendritic cells [8]

Etanercept (Enbrel): Etanercept is a receptor antibody fusion protein consisting of the two extracellular domain of the TNF- $\alpha$ receptor fused with the Fc portion of human IgG1 by three disulfide bonds. Etanercept bound to soluble TNF - $\alpha$ \& $\beta$ [9]. Recommended dose is $50 \mathrm{mg}$ subcutaneously twice weekly for 12 weeks followed by $50 \mathrm{mg}$ subcutaneously per week. It should be discontinued if patient do not reach PASI score of 50 by week 12. [9] Clinical response is expected between 4-8 weeks, in pediatric psoriasis $0.8 \mathrm{mg} / \mathrm{kg}$ maximum $(50 \mathrm{mg})$ weekly is recommended. [8]

\section{Pretreatment and monitoring investigations:}

all patient should have a thorough history, clinical examination, and investigation relevant to the known toxicity profile being used: full blood count, liver and renal function test screening for hepatitis and HIV infection, urine analysis, urine pregnancy test for female in child bearing age, chest $x$ ray, and tuberculin skin test. Monitoring of blood count, urine analysis, liver and renal function test are done at 3 month initially then every 6 months [10]. Investigation for hepatitis, HIV infection, pregnancy test repeated periodically for those at risk. Tuberculin skin test done annually and chest $X$ ray repeated only if clinically indicated [11]. Side effects of Etanercept include injection site reactions, tuberculosis, Viral hepatitis, risk of demyelinating disease, cardiovascular events, risk of malignancy, [8], paradoxical response of immune mediated disease to TNF _a inhibitorslting in psoriatic lesions [12]

\section{Patients and method}

This was theraputic, interventional comparative single center study carried out at the Center of AJODRR: https://escipub.com/american-journal-of-dermatological-research-and-reviews/ 
Dermatology and Venereology, Baghdad teaching hospital, from January 2015 -July 2017. A verbal consent was taken from all patients after full explanation of the study nature and ethical approval was obtained from the Scientific Council of Dermatology and Venereology-Iraqi Board for medical specialization. A total of 62 patients included in the study aged 15-65 years. All patients have chronic moderate to severe plaque psoriasis. The baseline PASI score $>10$, body surface area involved $>10 \%$ and DLQI $>10$ ) and patients with palmoplantar psoriasis were included in the study. Pregnant and lactating women, those with severe hepatic, renal, hematological or other systemic disorders, immunosuppressed patients, moderate to severe infection, lymphoproliferative, demyelinating disease, active or latent tuberculosis, positive virology for hepatitis or HIV infection, all were excluded from the study.

\section{The patients were divided into two groups:}

Group A: Treated with Etanercept; 33 patients, their ages range from $15-65$ with mean $\pm S D$ of $33.13 \pm 13.07$ years were recruited in this group, $23(69.69 \%)$ male and $10(30.30 \%)$ females. The patients were instructed to get Etanercept $50 \mathrm{mg}$ subcutaneous injection twice weekly for first 3 months then once weekly thereafter for a total of 6 months. All patients used etanercept (enbrel $\left.{ }^{\Theta}\right)$ manufactured by Pfizer company.

Group B: Treated with methotrexate ; 29 patients their ages range from 15-62 with mean $\pm S D$ of $38.16 \pm 15.2$ years were recruited in this group, $19(65.52 \%)$ male and $10(34.48 \%)$ female. They started treatment with $5 \mathrm{mg}$ test dose then $15 \mathrm{mg}$ weekly either oral (in three divided doses 12 hours apart) or intramuscular (single weekly injection) with the use of folic acid tablet ( $5 \mathrm{mg}$ per day) in days free of treatment, for 6 months then the dose had been tappered according to response to treatment .All patients were instructed to use methotrxate (Ebewe) 2.5 $\mathrm{mg}$ tablet or $50 \mathrm{mg}$ ampule, manufactured by Ebewe pharma. As described in table (1).
1.Patients with chronic, moderate to severe plaque psoriasis who fail to respond to topical treatment, PUVA, acitritene, or previously used metotrexate with good response were selected for methotrexate group if not having a contraindication to it.

2. Patients with chronic, moderate to severe plaque psoriasis who fail to respond to topical treatment, PUVA, acitriten, methotrexate, cyclosporine or had contraindication for them were selected for etanercept group.

\section{Pretreatment assessment:}

Before starting the treatment, a full history was taken regarding the age, gender, occupation, residence, age of onset, duration of disease, seasonal variation, association with itching, history of previous therapy and family history. Careful physical examination regarding the size, site, erythema, scale, thickness of the plaque was carried out. Each patient in MTX group was sent for CBC with PLT count, AST, ALT, renal function test, serology for viral hepatitis and HIV and Pregnancy test for women of child bearing age as initial screening, then CBC with PLT count and AST, ALT after initial 5-10 mg test dose, CBC and PLT count and AST/ALT monthly for 4 months and then every 3-4 month if stable, as follow up monitoring. Each patient in Etanercept group sent for TST, CBC, serology for viral hepatitis and HIV, chest $x$ ray prior to treatment then $\mathrm{CBC}$ every 3 months and chest $x$ ray or TST annually or as clinically indicated. The severity and the extent of psoriasis were assessed by using PASI score and DLQI.

\section{PASI score performed by assessing [13]:}

1-Severity of psoriatic lesion; the body is divided into four parts: head, upper extremity, trunk and lower extremity. The psoriatic plaques were graded depends on three features; erythema, scaling and thickness and each was assigned from (0-4) with 4 being the worst. The three index scores are added up for each of the four body parts to give subtotals A1, A2, A3 and A4. Each one multiplied by fixed number that

\section{Selection criteria:}

AJODRR: https://escipub.com/american-journal-of-dermatological-research-and-reviews/ 
represent the surface area represented by that $B 1^{*}(0-6)=C 1$ part.

$\mathrm{B} 2 *(0-6)=\mathrm{C} 2$

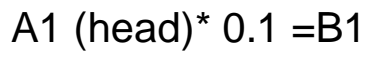

A2 (upper extremity) *0.2 $=\mathrm{B} 2$

$\mathrm{B3}^{*}(0-6)=\mathrm{C} 3$

A3 (trunk) *0.3 =B3

A4 (lower extremity) * $0.4=\mathrm{B} 4$

2-Area of psoriatic involvement of each part is scored from (0-6)

0: no lesion; 1:<10\%; 2: 10 to $<30 \% ; 3: 30$ to $<50 \%$; $4: 50$ to $<70 \%$; 5 : 70 to $<90 \%$; 6:90-100\%.

Then each of the body area scores are multiplied by the area affected:

$\mathrm{B}^{*}(0-6)=\mathrm{C} 4$

3-PASI score represent the summation of $\mathrm{C} 1+\mathrm{C} 2+\mathrm{C} 3+\mathrm{C} 4$ giving a range from $0-72$. In this study PASI score calculated manually.

DLQI score (Dermatology Life Quality Index): is a simple 10 questions questionnaire to assess the impact of psoriasis on patient's life.

It was calculated by asking the patients to fill the following questionnaire [14]:

\section{DERMATOLOGY LIFE QUALITY INDEX}

Hospital No: Date:

Name:

Diagnosis

DLQI

Address:

The aim of this questionnaire is to measure how much your skin problem has affected your life OVER THE LAST WEEK. Please tick one box for each question.

\begin{tabular}{|c|c|c|c|c|}
\hline 1. & $\begin{array}{l}\text { Over the last week, how itchy, sore, painful or stinging has your skin } \\
\text { been? }\end{array}$ & $\begin{array}{l}\text { Very much } \\
\text { A lot } \\
\text { A little } \\
\text { Not at all }\end{array}$ & \begin{tabular}{|l|}
$\square$ \\
$\square$ \\
$\square$ \\
$\square$
\end{tabular} & \\
\hline 2. & $\begin{array}{l}\text { Over the last week, how embarrassed or self conscious have you } \\
\text { been because of your skin? }\end{array}$ & $\begin{array}{l}\text { Very much } \\
\text { A lot } \\
\text { A little } \\
\text { Not at al }\end{array}$ & \begin{tabular}{l|}
$\square$ \\
$\square$ \\
$\square$ \\
$\square$
\end{tabular} & \\
\hline 3. & $\begin{array}{l}\text { Over the last week, how much has your skin interfered with you going } \\
\text { shopping or looking after your home or garden? }\end{array}$ & $\begin{array}{l}\text { Very much } \\
\text { A lot } \\
\text { A little } \\
\text { Not at all }\end{array}$ & \begin{tabular}{l|}
$\square$ \\
$\square$ \\
$\square$ \\
$\square$
\end{tabular} & Not relevant $\square$ \\
\hline 4. & $\begin{array}{l}\text { Over the last week, how much has your skin influenced the clothes } \\
\text { you wear? }\end{array}$ & $\begin{array}{l}\text { Very much } \\
\text { A lot } \\
\text { A little } \\
\text { Not at all }\end{array}$ & \begin{tabular}{l|}
$\square$ \\
$\square$ \\
$\square$ \\
$\square$
\end{tabular} & Not relevant $\square$ \\
\hline 5. & $\begin{array}{l}\text { Over the last week, how much has your skin affected any social or } \\
\text { leisure activities? }\end{array}$ & $\begin{array}{l}\text { Very much } \\
\text { A lot } \\
\text { A little } \\
\text { Not at all }\end{array}$ & \begin{tabular}{l|}
$\square$ \\
$\square$ \\
$\square$ \\
$\square$
\end{tabular} & Not relevant $\square$ \\
\hline 6. & $\begin{array}{l}\text { Over the last week, how much has your skin made it difficult for you } \\
\text { to do any sport? }\end{array}$ & $\begin{array}{l}\text { Very much } \\
\text { A lot } \\
\text { A little } \\
\text { Not at all }\end{array}$ & \begin{tabular}{l|}
$\square$ \\
$\square$ \\
$\square$ \\
$\square$
\end{tabular} & Not relevant $\square$ \\
\hline \multirow[t]{2}{*}{7.} & $\begin{array}{l}\text { Over the last week, has your skin prevented you from working or } \\
\text { studying? }\end{array}$ & $\begin{array}{l}\text { yes } \\
\text { no }\end{array}$ & \begin{tabular}{|l|}
$口$ \\
$\square$
\end{tabular} & Not relevant $\square$ \\
\hline & $\begin{array}{l}\text { If "No", over the last week how much has your skin been a problem at } \\
\text { work or studying? }\end{array}$ & $\begin{array}{l}\text { A lot } \\
\text { A little } \\
\text { Not at al }\end{array}$ & $\begin{array}{l}\square \\
\square \\
\square\end{array}$ & \\
\hline 8. & $\begin{array}{l}\text { Over the last week, how much has your skin created problems with } \\
\text { your partner or any of your close friends or relatives? }\end{array}$ & $\begin{array}{l}\text { Very much } \\
\text { A lot } \\
\text { A little } \\
\text { Not at all }\end{array}$ & \begin{tabular}{l|}
$\square$ \\
$\square$ \\
$\square$ \\
$\square$
\end{tabular} & Not relevant $\square$ \\
\hline 9. & $\begin{array}{l}\text { Over the last week, how much has your skin caused any sexual } \\
\text { difficulties? }\end{array}$ & $\begin{array}{l}\text { Very much } \\
\text { A lot } \\
\text { A little } \\
\text { Not at all }\end{array}$ & \begin{tabular}{l|}
$\square$ \\
$\square$ \\
$\square$ \\
$\square$
\end{tabular} & Not relevant $\square$ \\
\hline 10. & $\begin{array}{l}\text { Over the last week, how much of a problem has the treatment for your } \\
\text { skin been, for example by making your home messy, or by taking up } \\
\text { time? }\end{array}$ & $\begin{array}{l}\text { Very much } \\
\text { A lot } \\
\text { A little } \\
\text { Not at all }\end{array}$ & $\begin{array}{l}\square \\
\square \\
\square \\
\square\end{array}$ & Not relevant $\square$ \\
\hline
\end{tabular}

Please check you have answered EVERY question. Thank you.

AJODRR: https://escipub.com/american-journal-of-dermatological-research-and-reviews/ 
Scoring given for each question is as the following:

Very much scored 3

A lot scored 2

A little scored 1

Not at all scored 0

Not relevant scored 0

Q. unanswered scored 0

Q.7 prevented work or studying scored 3

DLQI obtained by calculating the score for each question, maximum score can be obtained is 30 and a minimum score is zero. The higher the score is the more impact on the patient life.

Then the score interpreted to affect the patient life as following:

$0-1=$ no effect on patient life.

$2-5=$ small effect on patient life.

$6-10=$ moderate effect on patient life.

$11-20=$ very large effect on patient life.

21-30= extremely large effect on patient life.

Patients in the study were asked to stop any topical and systemic treatment and only emollients were allowed to be used. Married female patient of reproductive age were advised to use contraceptive method during treatment period. Photographs were taken for each patient at the first visit and with each follow up visit using Sony digital, high sensitivity, 14.1 mega pixels in same place with fixed illumination and distance. The baseline PASI score for group A range from 10.1-50.4 with mean $\pm S D$ 19.13 \pm 10.67 , while that for group B range from 10.1-49 with mean $\pm S D$ 18.97 \pm 10.54 . Their DLQI score interpreted as moderate, very large effect and extremely large effect on the patient's life quality for both groups.

Clinical response was assessed by measuring PASI score, DLQI with each visit. Safety assessment done by routine laboratory parameters and reporting the side effect with each visit.

\section{Statistical analysis:}

For determination of statistical significance among different variables, descriptive statistics (mean and standard deviation) were used together with analytic statistics (t-test,F-test ). P values $<0.05$ were considered to indicate statistical significance.

Table (1): Demographic characteristics of group (I) and group (II).

\begin{tabular}{|l|l|l|l|}
\hline \multicolumn{2}{|c|}{ Groups } & $\begin{array}{l}\text { Group I:(Etanercept) } \\
\text { NO=30 }\end{array}$ & $\begin{array}{l}\text { Group II: (MTX) } \\
\text { NO 25 }\end{array}$ \\
\hline \multirow{2}{*}{ Patients characteristics (years) } & Range & $15-65$ & $15-62$ \\
\cline { 2 - 4 } & Mean \pm SD & $33.13 \pm 13.07$ & $38.16 \pm 15.2$ \\
\hline \multirow{2}{*}{ Gender } & Male & 23 & 19 \\
\cline { 2 - 5 } & Female & 10 & 10 \\
\hline \multirow{2}{*}{ PASI score at baseline mean $\pm S D$} & $19.13 \pm 10.67$ & $18.97 \pm 10.54$ \\
\hline
\end{tabular}

\section{Results}

A total of 62 patients were subjected in the present study for treatment with etanercept and MTX. Seven patients defaulted from the study for unknown reason, so 55 patients completed the study. The patients response to treatment was assessed after 4,12 and 24 weeks of treatment.

\section{Group I (Etanercept group):}


A total of 33 patients were enrolled in this group. Only 30 patients complete 6 months of treatment. The results were as the following:

Regarding PASI score:

1. After 4 weeks of treatment mean \pm SD PASI score reduced from baseline $19.13 \pm 10.67$ to $13.94 \pm 10.732$ with P-value $=0.0655$

2. After 12 weeks of treatment, their mean \pm SD PASI score reduced to $6.38 \pm 4.96$ with significant $P$-value $<0.0001$.

3. After 24 weeks of treatment mean \pm SD PASI score reaches $3.34 \pm 5.38$ with significant $P$ value $<0.0001$. As shown in table (2).

After 4 weeks of treatment with etanercept; 2 (6.66\%) patients achieved 50-75\%, 4 (13.33\%) patients achieved $75-90 \%, 1$ (3.33\%) patient achieved $>90 \%, 3(10 \%)$ patients achieved 25 $50 \%, 20(66 \%)$ patients achieved $0-25 \%$ reduction in their PASI score. After 12 weeks of treatment; $8(26.33 \%)$ patients achieved 50$75 \%, 13$ (43.33\%) patients achieved $75-90 \%, 2$ $(6.66 \%)$ patients achieved $>90 \%$, reduction in PASI score and considered as good responders, and $3(10 \%)$ patients achieved $25-50 \%$ and 4(13.33) patients achieved $0-25 \%$, reduction in PASI score. After 24 weeks of treatment; 1(3.33\%) patients achieved 50-75\%, 5 (16.66\%) patients achieved $75-90 \%, 11(36.66 \%)$ patients achieved $>90 \%$, reduction in PASI score , while 8 (26.66\%) patients achieved complete clearance, 3 (10\%) patients achieved 25-50\% reduction in their PASI score and received MTX in addition to etanercept, two of them have palmoplanter psoriasis, while the last two $(6.66 \%)$ patients developed $0-25 \%$ reduction after initial mild response and considered as non-responders and stopped treatment. table (4).

\section{Regarding their DLQI:}

The mean \pm SD DLQI score reduced from baseline $22.66 \pm 5.05$ to $14.97 \pm 8.16,6.46 \pm 6.5$, $3.36 \pm 7.6$ after 4,12 and 24 weeks of treatment respectively with $\mathrm{P}$-value $<0.0001$ for each, as shown in table (3).

Their DLQI changes during different weeks of treatment with etanercept were described in table (5).

Side effects recorded during treatment period were; $2(6.66 \%)$ patients developed boils of scalp and trunk that respond to ordinary treatment, $1(3.33 \%)$ patient developed psoriasis at the site of injection and another one (3.33\%) developed injection site reaction that resolved spontaneously.

Table (2): PASI score Mean \pm SD with $P$ value during treatment with Etanercept.

\begin{tabular}{|l|l|l|}
\hline Weeks & $\begin{array}{l}\text { PASI } \\
\text { Mean } \pm \text { SD }\end{array}$ & P-value \\
\hline Baseline visit & $19.13 \pm 10.67$ & 0.0655 \\
After 4 weeks & $13.94 \pm 10.732$ & $<0.0001$ \\
\hline Baseline visit & $19.13 \pm 10.67$ & $<0.0001$ \\
\hline After 12 weeks & $6.38 \pm 4.96$ & \\
\hline Baseline visit & $19.13 \pm 10.67$ & \\
After 24 weeks & $3.34 \pm 5.38$ & \\
\hline $\begin{array}{l}\text { F-test=21.86 } \\
\text { P-value<0.0000001 }\end{array}$ & \\
\hline
\end{tabular}


Table (3): DLQI Mean \pm SD with P value during treatment with Etanercept.

\begin{tabular}{|l|l|l|}
\hline Weeks & $\begin{array}{l}\text { DLQI } \\
\text { Mean } \pm \text { SD }\end{array}$ & P-value \\
\hline Baseline visit & $22.66 \pm 5.05$ & $<0.0001$ \\
After 4 weeks & $14.97 \pm 8.16$ & $<0.0001$ \\
\hline Baseline visit & $22.66 \pm 5.05$ & \\
After 12 weeks & $6.46 \pm 6.5$ & $<0.0001$ \\
\hline Baseline visit & $22.66 \pm 5.05$ & \\
\hline After 24 weeks & $3.36 \pm 7.6$ & \\
\hline $\begin{array}{l}\text { F-test }=\mathbf{4 7 . 4 2} \\
\text { P-value }<0.0000001\end{array}$ & & \\
\hline
\end{tabular}

Table (4): Reduction rate in PASI score during treatment with etanercept.

\begin{tabular}{|l|l|l|l|}
\hline Reduction rate & $\begin{array}{l}\text { No. of patients } \\
\text { After 4 weeks }\end{array}$ & $\begin{array}{l}\text { No. of patients } \\
\text { After 12 weeks }\end{array}$ & $\begin{array}{l}\text { No. of patients } \\
\text { After 24 weeks }\end{array}$ \\
\hline Complete clearance & ------- & ------- & $8(26.33 \%)$ \\
\hline$>\mathbf{9 0} \%$ & $1(3.33 \%)$ & $2(6.66 \%)$ & $11(36.66 \%)$ \\
\hline $\mathbf{7 5 - 9 0 \%}$ & $4(13.33 \%)$ & $13(43.33 \%)$ & $5(16.66 \%)$ \\
\hline $\mathbf{5 0 - 7 5 \%}$ & $2(6.66 \%)$ & $8(26.33 \%)$ & $1(3.33 \%)$ \\
\hline $\mathbf{2 5 - 5 0} \%$ & $3(10 \%)$ & $3(10 \%)$ & $3(10 \%)$ \\
\hline $\mathbf{0 - 2 5 \%}$ & $20(66 \%)$ & $4(13.33 \%)$ & $2(6.66 \%)$ \\
\hline
\end{tabular}

Table (5): Effect of psoriasis on patient life quality in Etanercept group before and after treatment.

\begin{tabular}{|l|l|l|l|l|}
\hline Effect & $\begin{array}{l}\text { No of patient before } \\
\text { treatment }\end{array}$ & $\begin{array}{l}\text { No of patient after } \mathbf{4} \\
\text { weeks treatment }\end{array}$ & $\begin{array}{l}\text { No. of patient after 12 } \\
\text { weeks }\end{array}$ & $\begin{array}{l}\text { No. of patient after 24 } \\
\text { weeks }\end{array}$ \\
\hline $\begin{array}{l}\text { Extremely } \\
\text { large }\end{array}$ & 21 & 8 & 2 & 2 \\
\hline Very large & 8 & 12 & 4 & 3 \\
\hline Moderate & 1 & 4 & 2 & --- \\
\hline Small & --- & 5 & 18 & 2 \\
\hline No effect & --- & 1 & 4 & 23 \\
\hline
\end{tabular}




\section{Group II (MTX group):}

A total of 29 patients were enrolled in this group. Only 25 completed the study.

The results of treatment with MTX were as the following:

\section{Regarding PASI score:}

1. After 4 weeks of treatment mean \pm SD PASI score reduced from baseline $18.97 \pm 10.54$ to $12.276 \pm 8.131$ with $P$-value $=0.01$

2. After 12 weeks of treatment mean \pm SD PASI score reduced to $5.72 \pm 4.8$ with significant $P$ value $<0.0001$.

3. After 24 weeks of treatment mean \pm SD PASI score reduced to $2.95 \pm 6.01$ with significant P-value <0.0001. table (6).

After 4 weeks of treatment; 8(32\%) patients achieved $50-75 \%, 7(28 \%)$ patients achieved 25 $50 \%, 10(40 \%)$ patients developed 0-25\%, reduction in their PASI score.

After 12 wks treatment; 8(32\%)patients achieved 50-75\%, 5(20\%)patients achieved 75$90 \%, 4(16 \%)$ patients achieved $>90 \%$, reduction in PASI score, 2(8\%) patients achieved complete clearance, while 5(20\%)patients achieved $25-50 \%$, and $1(4 \%)$ achieved $0-25 \%$, reduction in PASI score.

After 24 wks treatment; 5(20\%)patients achieved $75-90 \%, \quad 6 \quad$ (24\%)patients achieved $>90 \%$ reduction in PASI score, $10(40 \%)$ patients achieved complete clearance, $1(4 \%)$ patient achieved $25-50 \%$ reduction in PASI score, $3(12 \%)$ patients achieved $0-25 \%$ $\%$ reduction and shifted to other modalities of treatment.

table (8).

\section{Regarding DLQI:}

The mean \pm SD DLQI reduced from baseline $20.76 \pm 4.76$ to $9.32 \pm 5.467,5.04 \pm 4.44,2.52 \pm 5.58$ after 4,12 and 24 weeks of treatment respectively, with significant $P$-value $<0.0001$ for each, as in table (7).

The DLQI change during treatment with methotrexate described in tables (9).

Regarding side effect; 12 (48\%) patients complained Gl disturbance that improved with ordinary treatment or change to intramuscular rout, 4 (16\%) patients complained fatigue and muscle pain, 2 (8\%) patients complained headache.

Table (6): PASI score Mean \pm SD with P value during treatment with MTX.

\begin{tabular}{|l|l|l|}
\hline Weeks & $\begin{array}{l}\text { PASI } \\
\text { Mean } \pm \text { SD }\end{array}$ & P-value \\
\hline Baseline visit & $18.97 \pm 10.54$ & 0.01 \\
\hline After 4 weeks & $12.276 \pm 8.131$ & $<0.0001$ \\
\hline Baseline visit & $18.97 \pm 10.54$ & \\
\hline Baseline visit 12 weeks & $5.72 \pm 4.8$ & $<0.0001$ \\
\hline After 24 weeks & $18.97 \pm 10.54$ & \\
\hline $\begin{array}{l}\text { F-test=21.67 } \\
\text { P-value }<0.000001\end{array}$ & $2.95 \pm 6.01$ & \\
& & \\
\hline
\end{tabular}


Table (7): DLQI Mean \pm SD with $P$ value during treatment with MTX.

\begin{tabular}{|l|l|l|}
\hline Weeks & $\begin{array}{l}\text { DLQI } \\
\text { Mean } \pm \text { SD }\end{array}$ & $<0.0001$ \\
\hline Baseline visit & $20.76 \pm 4.76$ & \\
\hline After 4 weeks & $9.32 \pm 5.467$ & $<0.0001$ \\
\hline Baseline visit & $20.76 \pm 4.76$ & \\
After 12 weeks & $5.04 \pm 4.44$ & $<0.0001$ \\
\hline Baseline visit & $20.76 \pm 4.76$ & \\
\hline After 24 weeks & $2.52 \pm 5.58$ & \\
\hline $\begin{array}{l}\text { F-test }=51.71 \\
\text { P-value }<0-0000001\end{array}$ & & \\
\hline
\end{tabular}

Table (8) : Reduction rate in PASI score during treatment with MTX.

\begin{tabular}{|l|l|l|l|}
\hline Reduction rate & $\begin{array}{l}\text { No. of patients } \\
\text { After 4 weeks }\end{array}$ & $\begin{array}{l}\text { No. of patients } \\
\text { After 12 weeks }\end{array}$ & $\begin{array}{l}\text { No. of patients } \\
\text { After 24 weeks }\end{array}$ \\
\hline Complete clearance & ------- & $2(8 \%)$ & $10(40 \%)$ \\
\hline$>\mathbf{9 0} \%$ & ------ & $4(16 \%)$ & $6(24 \%)$ \\
\hline $\mathbf{7 5 - 9 0 \%}$ & ------ & $5(20 \%)$ & $5(20 \%)$ \\
\hline $\mathbf{5 0 - 7 5 \%}$ & $8(32 \%)$ & $8(32 \%)$ & ----- \\
\hline $\mathbf{2 5 - 5 0 \%}$ & $7(28 \%)$ & $5(20 \%)$ & $1(4 \%)$ \\
\hline $\mathbf{0 - 2 5 \%}$ & $10(40 \%)$ & $1(4 \%)$ & $3(12 \%)$ \\
\hline
\end{tabular}

Table (9): Effect of psoriasis on patient life quality in MTX group before and after treatment.

\begin{tabular}{|l|l|l|l|l|}
\hline Effect & $\begin{array}{l}\text { No. of patient } \\
\text { before } \\
\text { treatment }\end{array}$ & $\begin{array}{l}\text { No. of patient after 4 } \\
\text { weeks treatment }\end{array}$ & $\begin{array}{l}\text { No. of patient after } \\
\mathbf{1 2} \text { weeks }\end{array}$ & $\begin{array}{l}\text { No. of patient after } \\
\text { 24 weeks }\end{array}$ \\
\hline Extremely large & 11 & ---- & --- & --- \\
\hline Very large & 14 & 10 & 3 & 3 \\
\hline Moderate & --- & 6 & 6 & --- \\
\hline Small & --- & 9 & 12 & 2 \\
\hline No effect & --- & --- & 4 & 20 \\
\hline
\end{tabular}



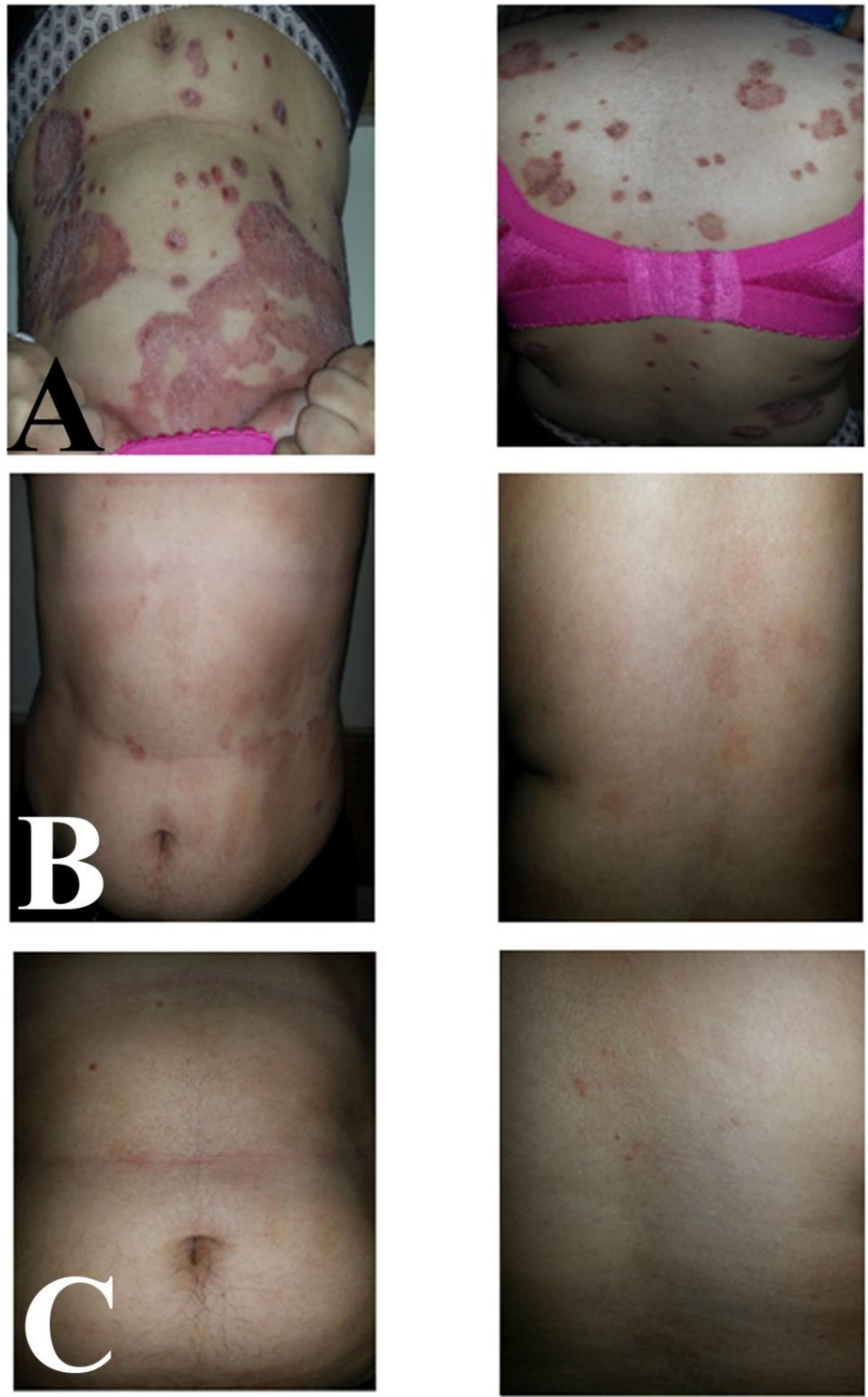

Figure (1): 23 years old female with plaque psoriasis treated with Etanercept. (A): Before treatment. (B): After 12 weeks. (C): After 24 weeks 

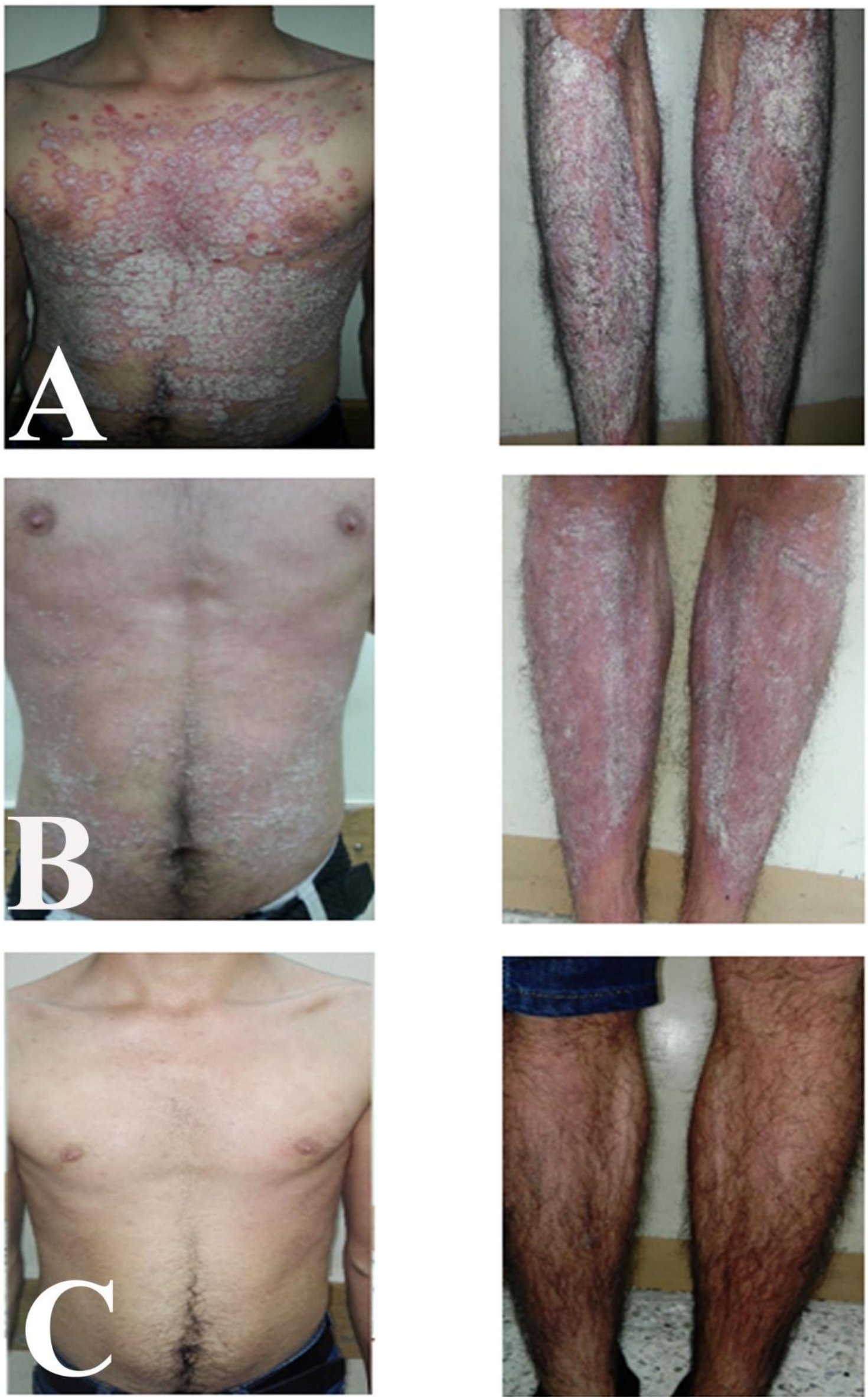

Figure (2): 24 years old male with plaque psoriasis treated with Etanercept. (A): Before treatment. (B): After 12 weeks. (C): After 24 weeks 

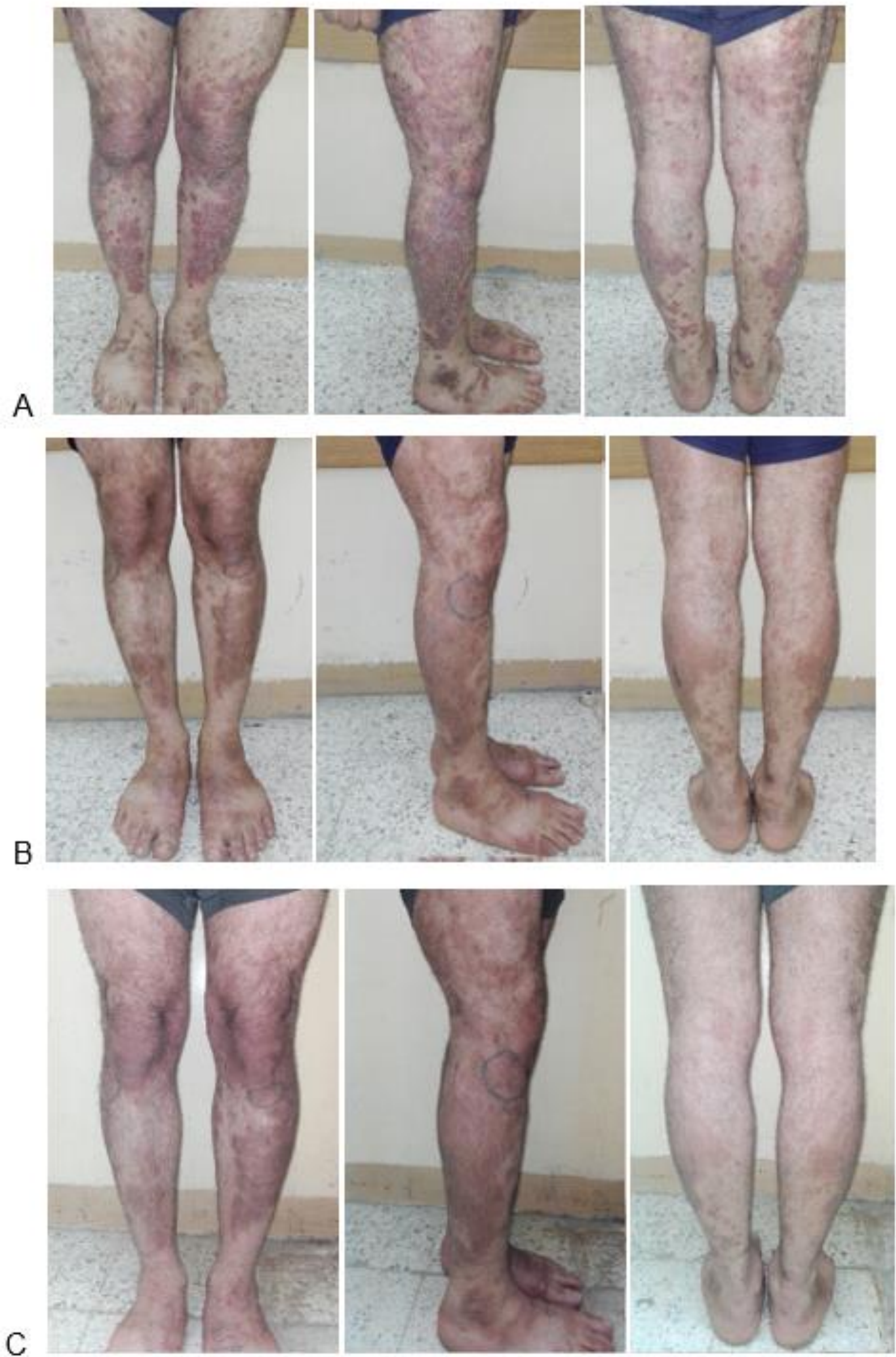

Figure (3): 31 years old male with plaque psoriasis treated with MTX. (A): Before treatment. (B): After 12 weeks. (C): After 24 weeks 

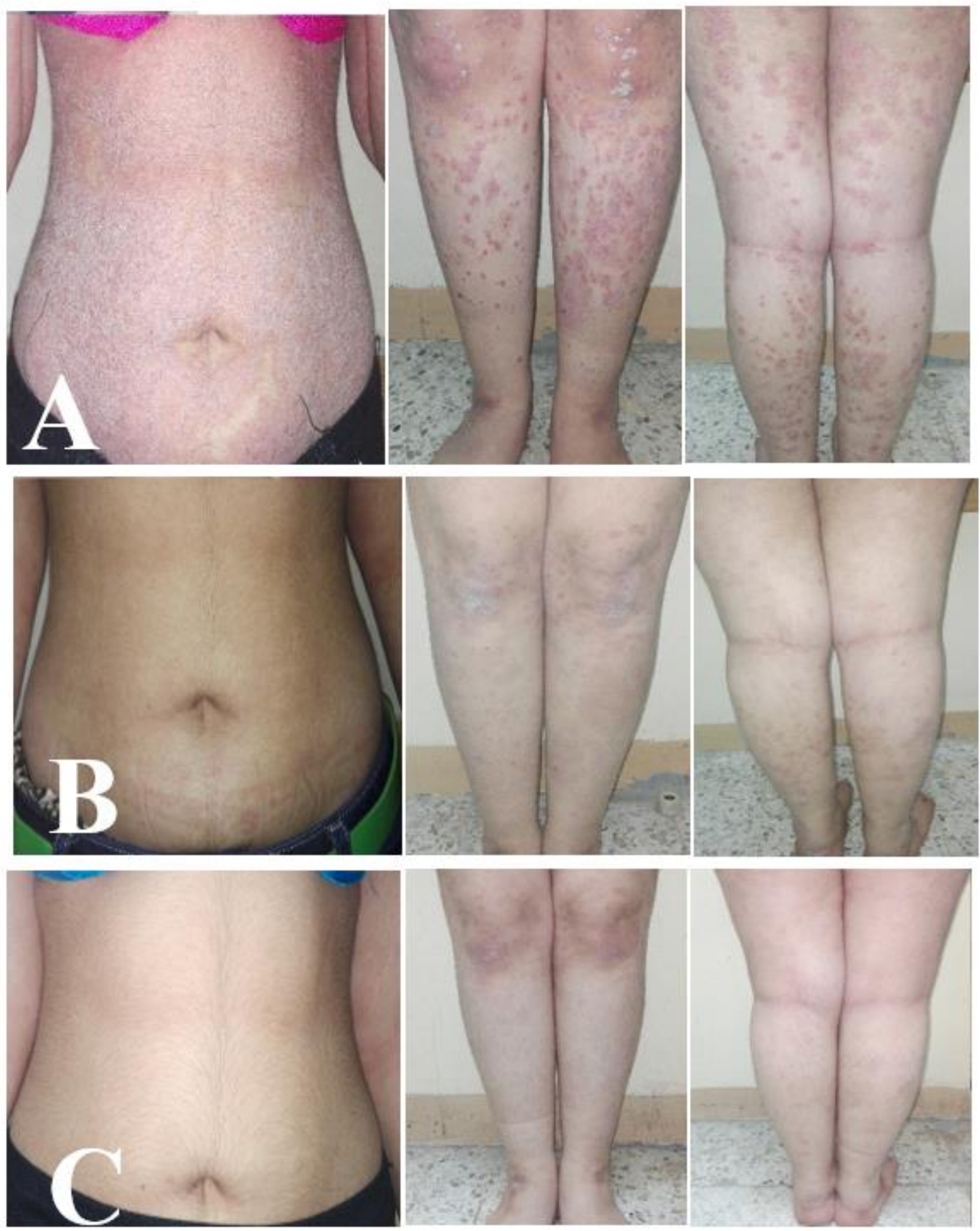

Figure (4): 18 years old male with plaque psoriasis treated with MTX. Before treatment. (B): After 12 weeks. (C): After 24 weeks

\section{Discussion}

Psoriasis is a common, chronic, relapsing, inflammatory, skin disease. Its severity may be mild that can be treated with topical modalities to moderate-severe that need different systemic modalities for treatment such as methotrexate, cyclosporine, acitriten and biological agents. All of these agents have serious systemic side effect starting from systemic immunosuppressant, renal, liver and bone marrow toxicity ending with carcinogenic and teratogenic effect which make them not suitable for selected patients [15]. Since psoriasis is hyper proliferative disorder in which both adaptive and innate immunity play important roles and greater understanding of the immunopathology of psoriasis was developed 
more targeted therapy have emerged with apparently fewer side effects [16].

In this study both etanerecpt and methotrexate were effective; apart from its cost, patients on etanercept where comfortable and more complianed to treatment as it is a new therapeutic agents and being free of side effects they complained previously with other modalities; while patients treated with methotrexate were afraid of infertility, hair loss and hepatotoxicity. Gubner et al in 1951 noted the fast clearing of psoriatic skin lesions in patients with psoriatic arthriris who were managed with antimetabolic drug aminopterin. Later on this drug was replaced by less toxic derivative methotrexate [17]. Despite its wide spread use in the treatment of psoriasis there is little evidence on safety of using methotrexate in patient with psoriasis. Although it has had a long history of use, there is no significant data on cumulative doses of MTX that result in early hepatic toxicity [18]. In study which was conducted by R. Baissonnette, he demonstrated that using etanercept at dose of $50 \mathrm{mg}$ subcutaneously twice per week has been shown to induce PASI 75 response to treatment in $49 \%$ of patients after 12 weeks [8], this was consistent with our study. In study which was conducted by Papp et al, they reduced the dose to $25 \mathrm{mg}$ twice per week for additional 12 weeks and they found that the patient percentage exhibiting PASI 75 response was increased to 54\% [19]. Pharmacogenitics represent the new frontier for discovery of potential genetic marker of biological response to etanercept. Clinical study showed that TNF- $\alpha-308 G \backslash G$, IL-17F (rs 763780), +489GG favor response to etanercept.Improvement in the knowledge of pharmacogenomic can make it possible to tailor treatment accordingly and to lower the unnecessary toxicity in patients receiving Etanercept [20]. In study conducted by Kenneth B. Gordon et al. they found that PASI 25 achievement at week 4 was highly predictive of response to methotrexate at 16 weeks. Patients with a predicted response probability less than
$30 \%$ were recommended to discontinue therapy. The rate of week 16 PASI 75 response were $65.8 \%$ and $21 \%(\mathrm{P}<0.001)$ for patients whom were recommended to continue and discontinue to MTX therapy, respectively [21]. In study conducted by U.F et al they found that low dose of MTX ( $<15-20 \mathrm{mg}$ per week) is an effective therapy for extensive and severe form of psoriasis if patient were selected carefully and monitored regularly, they observe that the effect was good in $76 \%$, moderate in $18 \%$ and poor in $6 \%$ of subjects [18].

MTX has been associated with significant gastrointestinal side effect, one method of reducing of these side effect is by divided the dose. Wienstein and Frost, were first proposed to divide the dose of methotrexate for psoriasis in 1971 . They showed small dose of $2.5-7.5 \mathrm{mg}$ given at interval of 12 hours for total three doses every week had an improvement from $75-100 \%$ in 26 patients with gastrointestinal side effect (nausea,oral ulcer and herpes) [22]. In our study we had 2 patients with palmoplantar psoriasis on etanercept who fail to respond adequately to treatment and need additional treatment with methotrexate after 6 months. This may suggest the poor response of this type of psoriasis to etanercept compared to a very good response in one patient with palmoplantar psoriasis in MTX group. This is inconsistent with a case report published by Weinberg JM who reported a successful treatment of recalcitrant palmoplantar psoriasis with etanercept in 59 years old woman unresponsive to other treatment modalities [23].

\section{Conclusion:}

We conclude that both MTX and etanercept are effective as monotherapy to treat patients with moderate to severe plaque psoriasis with tolerable side effects.

\section{DISCLOSURE}

This study was an independent study and not funded by any drug companies.

\section{REFERENCES}


1. Alissa C., Abby S., Van V. . Introduction: History of psoriasis and psoriasis therapy: Treatment of Psoriasis. Birkhäuser Verlag AG 2008; 1:1-9.

2. Raychaudhuri SP, Farber EM: The prevalence of psoriasis in the world. J Eur Acad Dermatol Venereol 2001; 15(1):16-17.

3. Al Yaschi M. Epidemiology and HLA typing of psoriasis in Iraq; Diploma thesis. College of Medicine, University of Baghdad. 1988.

4. Christophers E. Psoriasis-epidemiology and clinical spectrum. Clin Exp Dermatol. 2001;26:314-20

5. Kalb RE, Strober V., Weinstein G., Lebwohl M. Methotrexate and psoriasis: 2009 National Psoriasis Foundation Consensus Conference J Am Acad Dermatol 2009;60:824-37.

6. Carretero G., Puig L. , Dehesa L. , Carrascosa JM., Ribera $M$,et al. Guidelines on the Use of Methotrexate in Psoriasis. Actas Dermosifiliografica. 2010;101(7):600-613.

7. Anja W. , Amy C. Foulkes, N.J. Reynolds. Methotrexate Toxicity During Treatment of Chronic Plaque Psoriasis :A Case Report and Review of the Literature .Dermatol Ther (Heidelb). 2014 Dec; 4(2):145-146.

8. R. Bissonnette. Etanercept for the treatment of psoriasis. Available from http://www.skin therapyletter.com. [Reviewed: 2017 november].

9. Thao U Nguyen and John Koo. Etanercept in the treatment of plaque psoriasis. Clin Cosmet Investig Dermatol. 2009; 2:77-84.

10. Iffat $H$, Samia A, Gousia S, Parvias A. Biologics in dermatology: A brief review. British Journal of Medical Practitioners 2013:6(4) a629.

11. Smith $\mathrm{CH}$, Anstey Av, Barker JNWN, Burden AD, Chalmers RJ, Chandler DA. British association of dermatologists guidelines for biological intervention for psoriasis $2009 \mathrm{Br} \mathrm{J}$ Dermatol 2009; 161:987 1019.

12. Maria H, Melina M, Raimon S. Skin Lesions and Treatment with Tumo Necrosis Factor Alpha Antagonists. Rheumatol Clin 2013;9(1):53- 61.

13. Severity and extent of psoriasis (Psoriasis Area and Severity Index).http://www.dermnetnz.org/scaly/pasi.html. [accessed at 6/3/2014].

14. Qualityof life. Dermatologylife quality index. http://www.dermtology.org.uk/quality/dlqi/qualitydlqi.html. [accessed at 13/3/2014].

15. Menter A, Korman NJ.,Elmets CA., Gottlieb A, Feldman SR, Van Voorhees AS, Leonardi CL,
Gordon KB, Guidelines of care for the management of psoriasis and psoriatic arthritis, section 5. Guidelines of care for the management of psoriasis with physiotherapy and photochemotherapy. J Am Acad Dermatol 2010; 62:114-35.

16. Cindy D. Kipnis, Wendy A. Myers, Mobolaji Opeola, Alice B. Gottlieb. Biologic treatment for psoriasis. Available from http://dx.doi.org/10.1016/j.jaad.2004.12.032.

17. U-F, Haustein , M.Rytter. Methotrexate in psoriasis 26 years' experience with low dose long term treatment. JEADV,2000,14:382-8.

18. Bo Ri Kim, Jungyoon ohn, Chong won choi, Sang Woong Youn. Methotrexate in a real-world psoriasis treatment, it is really a dangerous medication for all?.Ann Dermatol,2017;29(3):3468.

19. Kim A Papp. The safety of etanercept for the treatment of plaque psoriasis, their Clin Risk Manage, 2017;3(2):245-8.

20. Giusepp M. et al. Impact of pharmacogenic upon the therapeutic response to etanercept in psoriasis and psoriatic arthritis, Expert opinion on drug safety, DOI:10.1080/14740338.2017.1361404.

21. Kenneth B. Gordon et al. Poor early response to methotrexate portends inadequate long-term outcomes in patient with moderate to severe psoriasis: Evidence from 2 phase 3 clinical trials, J Am Acad dermatol 2017. Available from http/dx.doi.org/10.1016/J.add.2017.08.017.

22. M.J.M. Rodrigues-Zuniga, F. Cortez-Franco, E. Qujiano- Gomero. Split doses of methotrexate in patients with severe psoriasis. ACTAS Dermosifiliogr, 2017.Available from http://dx.doi.org/10.1016/J.ad.2016.12.004.

23. Weinberg JM. Successful treatment of recalcitrant palmoplanter psoriasis with etanercept. Cutis. 2003 Nov;72(5):396-8.

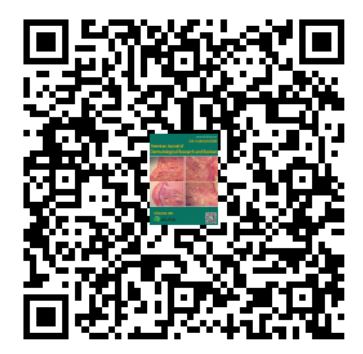

